\title{
Application of Value Analysis Techniques on a Rucksack: A Case Study
}

\author{
${ }^{1}$ Utkarsh Tiwari, ${ }^{2}$ Omprakash P, ${ }^{3}$ V.S. Giri \\ ${ }^{I}$ Department of Industrial Engineering and Management, Bangalore Institute of Technology \\ ${ }^{2}$ Department of Industrial Engineering and Management, Bangalore Institute of Technology \\ ${ }^{3}$ Department of Industrial Engineering and Management, Bangalore Institute of Technology \\ utkarshrko@gmail.com
}

\begin{abstract}
Manufacturers are allocating more of their resources to achieve customer delight by providing a better quality product and additional features at the lowest possible cost not only to acquire the market for existing product but also to increase and secure the demand for future products. With the increase in trend of travelling, the manufacturers need to meet and exceed the demands of their customers, the most vital demand of travellers are comfortable, reliable and multifunctional backpacks. Therefore, it become a necessity for manufacturers to control the cost and introduce new features to the rucksack. The aim of the paper "Application of Value Analysis Techniques on a Rucksack" is to perform a case study to improve and introduce new features in a rucksack through VA/VE methodology. The essence of value engineering technique involves the critical analysis of the functions of a product over all of its stages and producing a creative and innovative way to achieve the function at the lowest cost. Value analysis is an approach to improve the value of an item or process by understanding its constituent components and their associated costs. It then seeks to find improvements to the components by either reducing their cost or increasing the value of the functions. Upon application of VA methodology, a potential saving and multifunctionality is observed in the rucksack.
\end{abstract}

Keywords: value analysis, functional analysis, decision matrix, evaluation matrix, multifunctionality, rucksack, backpack.

\section{Introduction}

Value Analysis is a function oriented, systematic team approach to improve the value of a product, system or process by the critical assessment of the product, system or service to achieve their essential functions at the lowest cost without compromising its performance, reliability, quality and safety.

A bag is a common tool in the form of a non-rigid container. A rucksack is a bag which in its simplest form can be carried on one's back and is secured with two straps that go over shoulders. Rucksacks are often used by hikers, travellers and military to carry heavy loads and equipment.

\subsection{Concept of value:}

Value is the lowest cost to reliably provide the required function or service at a desired time and place within essential quality. It can be described by the below equation: 


$$
\text { - Value }=\frac{\text { Function }}{\text { Cost }}
$$

To Increase Value

$$
\begin{array}{ll}
\frac{\mathrm{F} \uparrow}{\mathrm{C} \downarrow} \quad \frac{\mathrm{F} \uparrow}{\mathrm{C}} \rightarrow \quad \frac{\mathrm{F}}{\mathrm{C}} \rightarrow \frac{\mathrm{F} \uparrow}{\mathrm{C} \uparrow} \\
\downarrow \text { REDUCE } \quad \uparrow \text { INCREASE } \longrightarrow \text { MAINTAIN }
\end{array}
$$

\subsection{Objectives of the Paper:}

1) To improve the functionality of the rucksack.

2) To make the rucksack ergonomic.

3) To reduce the cost of the rucksack.

4) To increase customer satisfaction

Value Engineering (VE), which is originated from the US military industry in the early 60 of this centuries, has been extensively applied in construction industry nowadays. Foo, T.H.(2002) and Chong, S.N.(2002) has given some useful frameworks on the application of VE. However, in India, VE is mostly associated to any alternative design with the intention of cost cutting exercise for a project, which is merely one of the initial intentions of the VE. This paper outlines the basic frameworks of Value Engineering and presents a case study showing the merits of VE in a Bath Fittings Manufacturing Industry.

\section{Review of Literature}

\subsection{Definition of Value Engineering}

Value Engineering is the systematic application of recognized techniques by multidisciplined team(s) that identifies the function of a product or service; establishes a worth for that function; generates alternatives using creative thinking; and provides the needed functions, reliably, at the lowest overall cost. Value Engineering may be defined in other ways, as long as the definition contains the following three basic precepts:

1. An organized review to improve value by using multi-disciplined teams of specialists knowing various aspects of the problem being studied.

2. A function oriented approach to identify the essential functions of the system, product, or service being studied, and the cost associated with those functions.

3. Creative thinking using recognized techniques to explore alternative ways of performing the functions at a lower cost, or to otherwise improve the design.

\subsection{What Value Engineering Isn't}

Value Engineering is not just "good engineering." It is not a suggestion program and it is not routine project or plan review. It is not typical cost reduction in that it doesn't "cheapen" the product or service, nor does it "cut corners." Value Engineering simply answers the question "what else will accomplish the purpose of the product, service, or process we are studying?" It stands to reason that any technique so useful should be applied to every product, and at each stage of the normal day-to-day development of a highway product. This is not the case. The practice of VE entails a certain amount of expense, that must be justified by potential cost savings. Accordingly, there must be a 
Budapest International Research in Exact Sciences (BirEx) Journal

Volume 2, No 1, January 2020, Page: 73-85

e-ISSN: 2655-7827 (Online), p-ISSN: 2655-7835 (Print)

www.bircu-journal.com/index.php/birex

emails: birex.journal@gmail.com

birex.journal.qa@gmail.com

recognized need for change and a distinct opportunity for financial benefit to warrant the added cost of a VE effort.

\subsection{Roadblocks to Cost Effectiveness}

The practice of VE doesn't imply that there may be intentional "gold plating," conscious neglect of responsibility, or unjustifiable error or oversight by the design team. VE simply recognizes that social, psychological, and economic conditions exist that may inhibit good value. The following are some of the more common reasons for poor value:

1. Lack of information usually caused by a shortage of time. Too many decisions are based on feelings rather than facts.

2. Wrong beliefs, insensitivity to public needs or unfortunate experience with products or processes used in unrelated prior applications.

3. Habitual thinking, rigid application of standards, customs, and tradition without consideration of changing function, technology, and value.

4. Risk of personal loss, the ease and safety experienced in adherence to established procedures and policy.

5. Reluctance to seek advice, failure to admit ignorance of certain specialized aspects of project development.

6. Negative attitudes, failure to recognize creativity or innovativeness.

7. Over specifying, costs increase as close tolerances and finer finishes are specified. Many of these are unnecessary.

8. Poor human relations, lack of good communication, misunderstanding, jealousy, and normal friction between people are usually a source of unnecessary cost. In complex projects, requiring the talents of many people, costs may sometimes be duplicated, and redundant functions may be provided.

Cooper and Slagmulder, in their book, comprehensively discussed the interaction between the target costing method and value engineering. They elaborately present the Survival Zone for a product that consists of three characters:

Price

Function

Quality

They discussed how these three factors interact with each other and provide the Zone for the operations of the firm. This Survival Zone is presented in Figure 1. The interaction of price and functionality was, also, discussed by them. Here, an attempt has been made to incorporate the third method (QFD) in this set. It is believed that a mathematical model is the proper tool for this incorporation and its feasible region precisely demonstrates the Survival Zone, which was described in.

\subsection{Five Phases of Ve Process During Design Phase}

Information Phase - During this phase, the VE team gathers as much information as possible about the program requirements, project design, background, constraints, and estimated/projected costs. The team performs functional analysis of systems and subsystems to identify high cost areas. The project designer provides additional design data and participates in the initial VE team conference. 


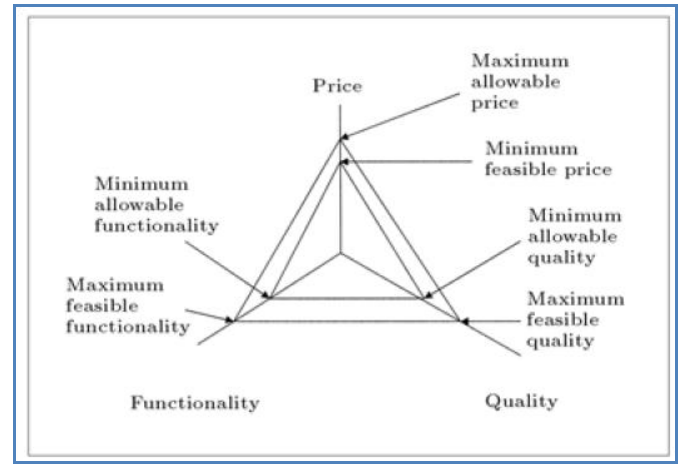

Figure 1. The survival zone for a product source

Speculative/Creative Phase - The team uses a group interaction process to identify alternative ideas for accomplishing the function of a system or subsystem.

Evaluation/Analytical Phase - The ideas generated during the speculative/creative phase are screened and evaluated by the team. The ideas showing the greatest potential for cost savings and project improvement are selected for further study.

Development/Recommendation Phase - The team researches the selected ideas and prepares descriptions, sketches, and life cycle cost estimates to support the VE proposal (VEP) recommendations.

Report Phase - The team presents the VEP's to the Government during an oral presentation at the conclusion of the workshop. Shortly after the completion of the VE workshop, a preliminary

VE report encompassing the entire VE effort is prepared by the VE team leader and submitted to the Government.

\subsection{Measures Taken (Post-Study)}

The preliminary VE report addresses any and all pertinent data or information that resulted from the study. Information typically will include, but is not limited to, an executive summary, a list of items or process examined, alternatives, functional and life cycle cost analyses, VEP's and supporting information such as a description of the difference between existing and proposed design, advantages, and disadvantages; a list and analysis of design criteria or specifications that must be changed if the VEP's are accepted by the Government; and the cost and schedule impact of the VEP's if implemented by the Government. After the preliminary VE report is discussed with the project designer and the Government decisions are made, the VE team will prepare a final VE report to indicate those proposals that are accepted. In ARS, the decision to accept or reject VEP's is with the Research Program Representatives after consultation with the Engineering Project Manager and Contracting Officer for the project.

\subsection{Access to Success}

There are many keys to the success of a VA program and it is wise to consider these issues before commencing the project, as errors in the project plan are difficult to correct, without causing frustration, once the VA project has started. One of the most important initial steps in developing the VA process is to create a formal team of individuals to conduct the exercise. These individuals must be drawn from different parts of the business that affect the costs associated with design, manufacturing, supply and other relevant functions. In addition, the team must be focused on a product or product family in order to begin the exercise. Further key success factors include: 
a. Gain approval of senior management to conduct a Value Analysis exercise. Senior management support, endorsement and mandate for the VA project provide legitimacy and importance to the project within the business. This approval process also removes many of the obstacles that can prevent progress from being made by the team.

b. Enlist a senior manager as a champion of the project to report back directly to the board of directors and also to act as the program leader.

c. Once a program team has been developed it is important to select an operational leader to coordinate the efforts, monitor progress and to support the project champion. This leader will remain with the VA team throughout the life of the project and will be the central linking pin between the team and the senior management champion.

d. Establish the reporting procedure for the team and the timing of the project. This project plan needs to be formal and displayed as a means of controlling and evaluating achievements against time.

e. Present the VA concept and objectives of the team to all the middle and senior managers in the business. Widespread communication of the VA project is important so that other employees, particularly managers (who may not be involved directly with the process) understand the need to support the project either directly by assigning staff or indirectly

f. Maintain a list of those business functions that should receive a regular communication of progress even though they may not be directly involved with the project. This process allows other individuals in the business to be informed about the progress and findings of the group.

This form of promotion is important as it maintains a momentum and communicates the findings of the team as widely as possible.

g. Provide an office space and co-locate the team members where practical and possible to do so. The ability to locate a VA improvement group in one area of the business is important and assists the communication within the group. A convenient area can also be used to dismantle the product and also the walls of the area can be used to record, on paper charts, the issues that have been discovered by the team (and the associated actions that must be undertaken).

h. Select the product for the first study. Ideally the existing product, or family of products, will be one that is established, sells in volume and has a relatively long life expectancy. As such any improvement in the cost performance of the product will provide a large financial saving to the business

i. Write down the objectives of the project and the key project review points. Estimate the targets to be achieved by the project. These objectives provide a reference point and framework for the exercise. The objectives also focus attention on the outputs and achievements required by the company.

j. Select and inform any personnel who will act in a part time or temporary role during the project. This process is used to schedule the availability of key specialist human resources to support the team throughout the duration of the project.

Train the team in both the process of VA and in basic team building activities. It is important that all members understand the nature of the project and its importance. The initial team building exercises are also a good way of understanding the attitude of all members to the project - especially those with reservations or a negative attitude to what can be achieved. As with most team exercises there is a requirement to allow the team to build and bond as a unit. It is often difficult for individuals, drawn from throughout the factory, to understand the language that is used throughout the business and also to 
understand the 'design to market' process when their own role impacts on a small section of this large and complex process.

\section{Discussion}

A Rucksack is one of a widely used product by all kind of travellers, hikers, military and others. Seeing, the current trend in travelling and a high demand of comfortable backpacks. It can be clearly understood that rucksack has a major potential of advancement and value increments through the application of Value Analysis techniques. Thus, it has been selected to perform a case study.

The Case Study is carried out in the following steps:

a) Function analysis worksheet is prepared for different parts of the product.

b) Functional analysis is done for each part.

c) Numerical evaluation sheet is prepared.

d) Creativity Worksheet is made.

e) Alternatives are selected through decision matrix.

f) Recommendations are made.

g) Conclusion

\subsection{Information Phase}

In this phase relevant data and specifications of the rucksack is gathered and organised. Rucksacks are used to carry heavier loads and usually offload the largest part of the load onto padded hip belts, leaving the shoulder straps mainly for stabilising the load. This improves the potential to carry heavy loads, as the hips are stronger than the shoulders, and increases agility and balance.

\subsection{Specifications of Rucksack:}

Capacity: 50 litres.(General)

Dimensions: $38 \mathrm{cms} \times 7 \mathrm{cms}$ x $55 \mathrm{cms}$.

Materials: Cordura fabric, Nylon, Polyester, Canvas, Rip-Stop Nylon, PVC fabric Target Customers: Hikers, Travellers and Military.

\section{Regular Rucksack}
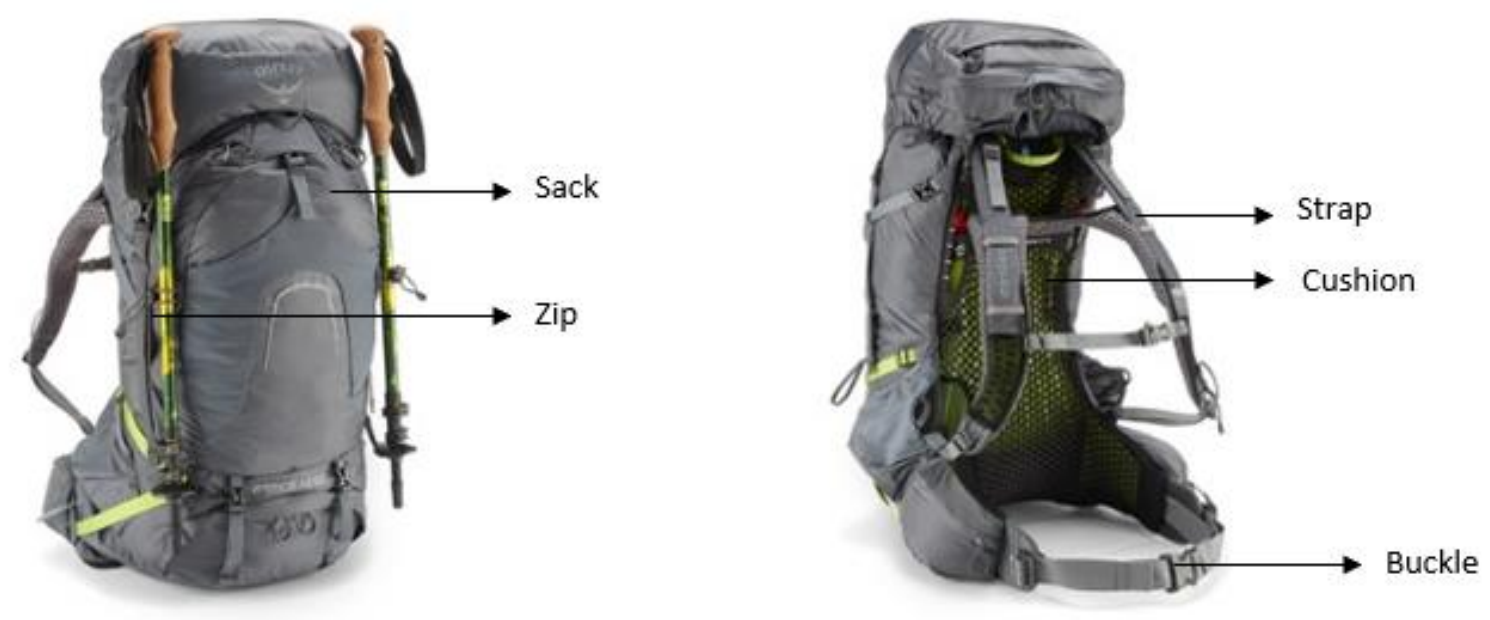


\subsection{Functional Phase}

Function phase is one of the important phases of value analysis techniques which is used to detect precise areas where unnecessary costs are involved.

With this objective in this phase the functions of the parts of the Rucksack are divided into two categories:

1) Basic function: The part that performs the main function required by the product.

2) Secondary function: A function that does not directly contribute to the main function but supports it instead. Functional Analysis: Detailed functional analysis of different parts of a rucksack is shown in Table 1.

Table 1. Function analysis- Identification of functions

\begin{tabular}{|l|l|l|l|l|l|l|}
\hline SL.NO & PART & Quantity & \multicolumn{2}{l|}{ FUNCTION } & \multicolumn{2}{l|}{ CATEGORY } \\
\cline { 4 - 7 } & \multirow{2}{*}{} & & \multicolumn{2}{l|}{} & \multicolumn{2}{l|}{} \\
\cline { 4 - 7 } & & VESCRIPTION & NOUN & BASIC & SECONDARY \\
\hline 1 & Sack & 1 & Store & Items & X & \\
\hline 2 & Straps & 2 & Support & Load & & X \\
\hline 3 & Zip & 6 & Secure & Item & & X \\
\hline 4 & Cushion & 1 & Provide & Comfort & & X \\
\hline 5 & Buckle & 2 & Support & Load & & X \\
\hline
\end{tabular}

Cost Worth Analysis: Detailed cost worth analysis of a rucksack is shown in Table 2.

Table 2. Function cost worth analysis- Ranking alternatives

\begin{tabular}{|l|l|l|l|l|l|l|}
\hline SL.NO & DESCRIPTION & FUNCTION & $\begin{array}{l}\text { PRESENT } \\
\text { COST }(\mathrm{C})\end{array}$ & $\begin{array}{l}\text { WORTH } \\
(\mathrm{W})\end{array}$ & $\begin{array}{l}\text { VALUE } \\
\text { GAP } \\
\text { (C-W) }\end{array}$ & RANKING \\
\hline 1 & Sack & Store Items & 1463 & 350 & 1113 & I \\
\hline 2 & Straps & $\begin{array}{l}\text { Support } \\
\text { Load }\end{array}$ & 250 & 50 & 200 & II \\
\hline 3 & Zip & Secure Item & 40 & 5 & 35 & V \\
\hline 4 & Cushion & $\begin{array}{l}\text { Provide } \\
\text { Comfort }\end{array}$ & 160 & 30 & 130 & Ill \\
\hline 5 & Buckle & $\begin{array}{l}\text { Support } \\
\text { Loads }\end{array}$ & 100 & 20 & 80 & IV \\
\hline
\end{tabular}




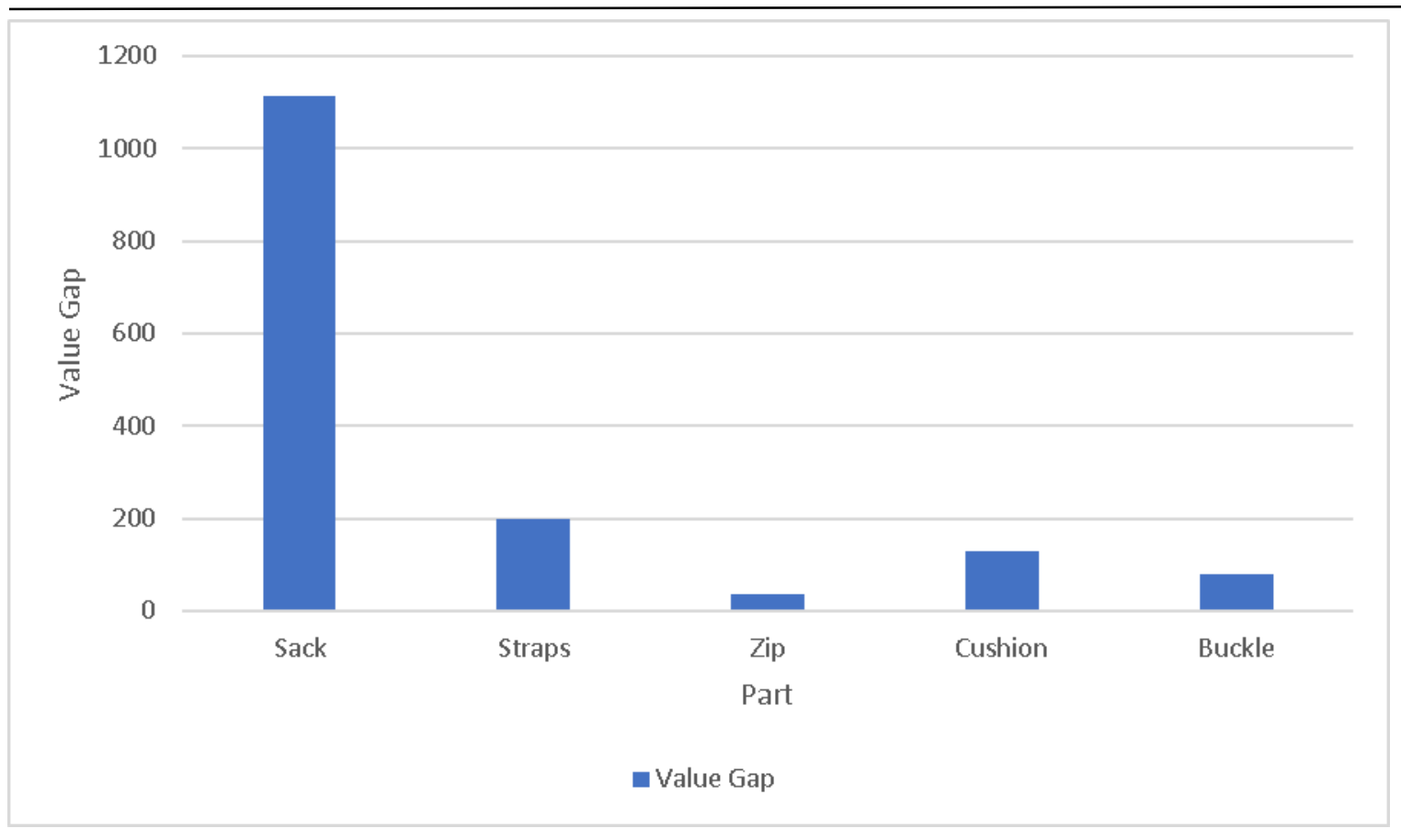

Graph 1. Part vs Value gap

The cost breakup for rucksack is shown in Table 3:

Table 3. Cost Breakup

\begin{tabular}{|l|l|l|l|}
\hline Key Letter & Part & Function & \% Cost \\
\hline A & Sack & Store Items & 72.67 \\
\hline B & Straps & Support Load & 12.41 \\
\hline C & Zip & Secure Items & 1.98 \\
\hline D & Cushion & Provide Comfort & 7.94 \\
\hline E & Buckle & Support Loads & 4.96 \\
\hline
\end{tabular}

Numerical Evaluation Sheet

A

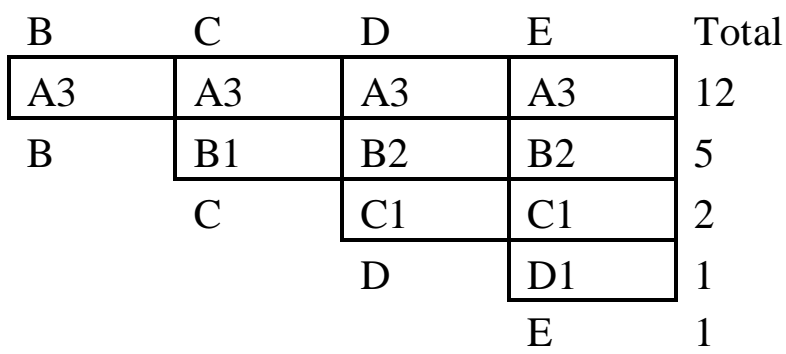

Major Performance-3

Medium Performance- 2

Minor Performance- 1 


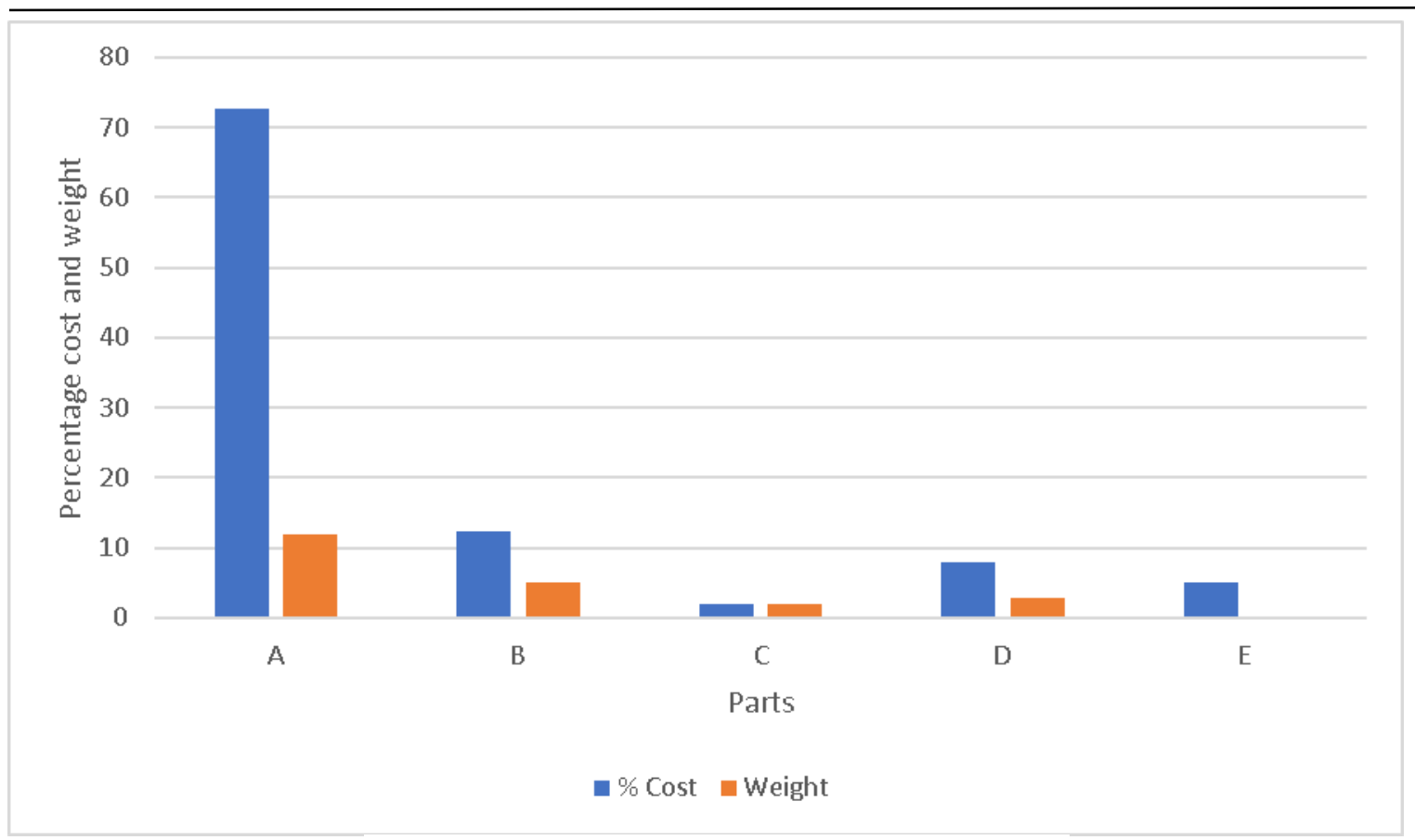

\subsection{Creative phase}

Graph 2. Parts vs Percentage cost and weight

The main aim of a creative phase is to find out what else maybe done in order to achieve the same function assuming cost as a constraint.

In this phase, team members used brainstorming technique to formulate new ideas for achieving the same functions which were drawn out through the discussion in functional phase. Through the brainstorming technique the following optimum alternatives were found:

1) Jute Bag

2) Sack

3) Canvas Bag

4) Leather Bag

5) Regular Rucksack

6) Multifunctional Rucksack- Inbuilt Sleeping Bag with attached Pillow, Valve On/Off Hydration Bladder, Phone and wallet pockets on Hip Belt, Inbuilt battery Packs.

\subsection{Evaluation phase}

In this stage, the ideas and alternatives generated in the creative phase are evaluated for their feasibility.

Table 4. Evaluation of Ideas generated from Creative phase

\begin{tabular}{|l|l|l|l|l|l|l|}
\hline $\begin{array}{l}\text { SI } \\
\text { No. }\end{array}$ & \multicolumn{1}{|c|}{ Ideas } & $\begin{array}{c}\text { State of } \\
\text { Art } \\
\text { 10: Off } \\
\text { Shelf } \\
\text { 1: New } \\
\text { Technology }\end{array}$ & $\begin{array}{c}\text { Cost of } \\
\text { Development } \\
\text { 10: No cost } \\
\text { 1: High cost }\end{array}$ & $\begin{array}{c}\text { Probability of } \\
\text { Implementation } \\
\text { 10: Excellent } \\
\text { chance } \\
\text { 1: No chance }\end{array}$ & $\begin{array}{c}\text { Functionality } \\
\text { 10: multi } \\
\text { 1: single }\end{array}$ & Rating \\
\hline $\mathbf{1}$ & Jute Bag & 10 & 8 & 3 & 1 & \\
\hline $\mathbf{2}$ & Sack & 10 & 9 & 1 & 1 & 22 \\
\hline $\mathbf{3}$ & Canvas Bag & 9 & 7 & 4 & 3 & 21 \\
\hline $\mathbf{4}$ & Leather Bag & 9 & 6 & 5 & 4 & 24 \\
\hline
\end{tabular}




\begin{tabular}{|l|l|l|l|l|l|l|}
\hline $\mathbf{5}$ & $\begin{array}{l}\text { Regular } \\
\text { Rucksack }\end{array}$ & 9 & 3 & 8 & 6 & 26 \\
\hline $\mathbf{6}$ & $\begin{array}{l}\text { Multifunctional } \\
\text { Rucksack }\end{array}$ & 7 & 3 & 10 & 10 & 30 \\
\hline
\end{tabular}

Table 5. Evaluation of alternatives with respect to features

\begin{tabular}{|l|l|l|l|l|l|l|}
\hline Ideas $\longrightarrow$ & 1 & 2 & 3 & 4 & 5 & 6 \\
& & & & & & \\
\hline Parameters & & & & & & \\
\hline Maintenance & 0 & 0 & 0 & 1 & 1 & 1 \\
\hline Appearance & 0 & 0 & 1 & 0 & 0 & 0 \\
\hline Ease of Use & 0 & 0 & 0 & 0 & 0 & 1 \\
\hline Compactness & 1 & 0 & 1 & 0 & 0 & 1 \\
\hline $\begin{array}{l}\text { Weather } \\
\text { Resistant }\end{array}$ & 0 & 0 & 0 & 0 & 1 & 1 \\
\hline Total & 2 & 1 & 3 & 2 & 3 & 5 \\
\hline$\%$ & 33.33 & 16.66 & 50 & 33.33 & 50 & 83.33 \\
\hline
\end{tabular}

1: YES 2: NO

\subsection{Development phase}

_In this stage the team develops the selected ideas into alternatives and their advantages and disadvantages are listed and ranked based on which it is determined if the alternative should be implemented.

Table 5. Evaluation Matrix

\begin{tabular}{|c|c|c|c|c|}
\hline$\stackrel{\text { Parameters }}{\longrightarrow}$ & $\begin{array}{l}\text { Ergonomic } \\
\text { Rating }\end{array}$ & $\begin{array}{l}\text { Weather } \\
\text { resistance } \\
\text { Rating }\end{array}$ & $\begin{array}{l}\text { Customer } \\
\text { Satisfaction } \\
\text { Rating }\end{array}$ & Total \\
\hline 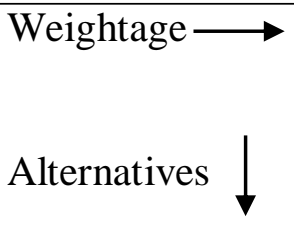 & 9 & 8 & 7 & \\
\hline $\begin{array}{l}\text { Multifunctional } \\
\text { rucksack }\end{array}$ & 4 & 3 & 4 & 88 \\
\hline $\begin{array}{l}\text { Regular } \\
\text { rucksack }\end{array}$ & 3 & 3 & 3 & 72 \\
\hline Leather Bag & 2 & 1 & 1 & \\
\hline
\end{tabular}




\begin{tabular}{|l|l|}
\hline 4 & Excellent \\
\hline 3 & Good \\
\hline 2 & Fair \\
\hline 1 & Poor \\
\hline
\end{tabular}

Table 6. Advantages and Disadvantages of Feasible Ideas

\begin{tabular}{|l|l|l|l|l|}
\hline S1. No. & Ideas & Ranking & Advantages & Disadvantages \\
\hline 1 & $\begin{array}{l}\text { Multifunctional } \\
\text { Rucksack }\end{array}$ & 1 & $\begin{array}{l}\text { Inbuilt } \\
\text { Accessories } \\
\text { Easy Handling } \\
\text { Compact }\end{array}$ & $\begin{array}{l}\text { Careful } \\
\text { handling of } \\
\text { inbuilt } \\
\text { accessories }\end{array}$ \\
\hline 2 & $\begin{array}{l}\text { Regular } \\
\text { Rucksack }\end{array}$ & 2 & $\begin{array}{l}\text { Storage } \\
\text { Capacity }\end{array}$ & $\begin{array}{l}\text { Bulky } \\
\text { Lack } \\
\text { accessories of }\end{array}$ \\
\hline
\end{tabular}

\subsection{Recommendation phase}

From the evaluation matrix( Table 5) and the alternatives comparison( Table 6) of development phase it is observed that the alternative "Multifunctional Rucksack" is preferred over the existing and other proposed alternatives.

The following table indicates the situation before and after the implementation of the proposed alternative.

Table 7. Before and After Comparison

\begin{tabular}{|l|l|}
\hline \multicolumn{1}{|c|}{ Situation Before- Regular Rucksack } & Situation After- Multifunctional Rucksack \\
\hline Bulky & Compact \\
\hline Inconvenient Handling & Hassle free handling \\
\hline Uneconomical & $\begin{array}{l}\text { Inbuilt Accessories (Sleeping Bag, } \\
\text { Hydration Bladder, Pillow, Battery Pack) }\end{array}$ \\
\hline Lack of accessories &
\end{tabular}


Budapest International Research in Exact Sciences (BirEx) Journal

Volume 2, No 1, January 2020, Page: 73-85

e-ISSN: 2655-7827 (Online), p-ISSN: 2655-7835(Print)

www.bircu-journal.com/index.php/birex

emails: birex.journal@gmail.com

birex.journal.qa@gmail.com

Cost Breakup for the exsisting and proposed alternative is shown in the following tables:

Table 8. Cost break up for the exsisting product with accessories

\begin{tabular}{|l|l|}
\hline Rucksack & $\mathbf{2 2 0 0}$ \\
\hline Sleeping Bag & $\mathbf{1 2 0 0}$ \\
\hline Pillow & $\mathbf{2 5 0}$ \\
\hline Water Bottle & $\mathbf{8 0}$ \\
\hline Power Bank & $\mathbf{6 5 0}$ \\
\hline Total Cost & $\mathbf{4 3 8 0}$ \\
\hline
\end{tabular}

Table 9. Cost break up for the proposed alternative

\begin{tabular}{|l|l|}
\hline Sack & 1500 \\
\hline Sleeping Bag (Inbuilt) & $\mathbf{2 0 0}$ \\
\hline Pillow (Inbuilt) & 0 \\
\hline Hydration Bladder & $\mathbf{3 0 0}$ \\
\hline Battery Pack (Inbuilt) & $\mathbf{4 5 0}$ \\
\hline Total Cost & $\mathbf{2 4 5 0}$ \\
\hline
\end{tabular}

\subsection{Presentation phase}

In this phase the cost of exsisting rucksack and multifunctional rucksack is observed and the savings achieved through value anlysis methodology is calculated. The percentage saving and toatl saving is indicated in the following table:

Table 10. Savings Achieved

\begin{tabular}{|l|l|}
\hline Present Cost (Rs) & 4380 \\
\hline Proposed Cost (Rs) & 2450 \\
\hline Saving (Rs) & 1930 \\
\hline \% Saving & 44.06 \\
\hline
\end{tabular}

The Proposed Alternative
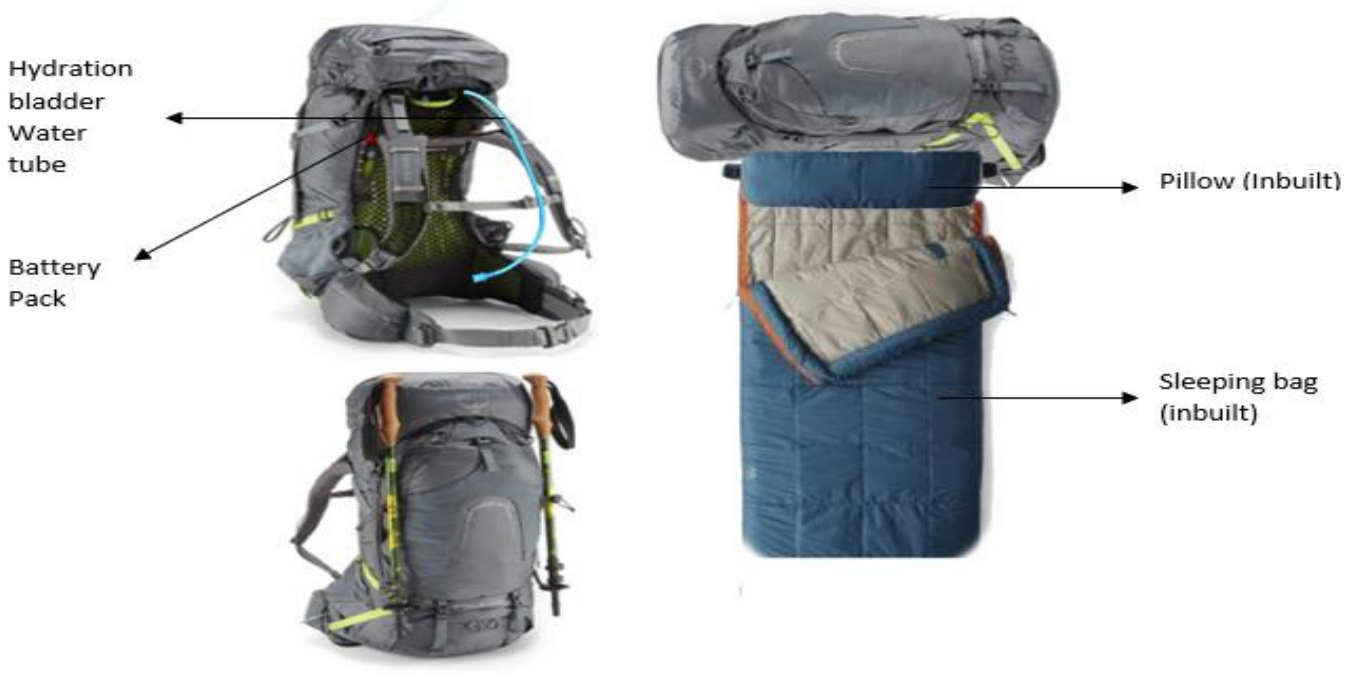

\subsection{Key points on Implementation}

- Return-on-investment 
- Inbuilt Accessories

- Lighter and Comfortable

- Increased functions

- Cost Effective and avoids high accessory cost

\section{Conclusion}

Value Analysis is recognized as an effective way to improve the performance of a product with reduction in cost and maintaining the quality. The quality of team (qualifications \& experience) for brainstorming session is a key ingredient to the success of the Value Analysis program. It is more effective and influential on the performance, quality, and cost of a product when done relatively early in the production schedule.

From this case study, it is observed that how Value Analysis techniques are used for increasing the function and the cost reduction can be obtained without changing the primary function of the product \& its values. An effective design matrix is prepared for choosing the appropriate alternative from the feasible choices available. The cost comparison is observed between the alternatives and the savings are calculated. On the selection of multifunctional Rucksack, a potential savings of Rs.1930 and a saving percentage of 44.06 was obtained.

\section{References}

A Novel Innovative Design Improvement Using Value Engineering Technique: A Case Study by Ali Mostafaeipour- Journal of Optimization in Industrial Engineering, June 2015.

Achieving Success through Value Engineering: A Case Study by Amit Sharma, R.M. Belokar, Member, IAENG October 2012.

Achieving Success through Value Engineering: A Case Study by Amit Sharma, R.M. Belokar, Member, IAENG October 2012.

Indian Value Engineering Society (1977-2017) - Survey of Forty Years and Selected Essays, Anil Mukhopadhyaya

Techniques of Value Analysis and Engineering, $2^{\text {nd }}$ Edition, Lawrence D Miles.

Value Analysis of steam iron for cost optimization by TATA Technologies - 34th INVEST International Conference, held on December 7,2019 in Mumbai.

Value Analysis of a Rubber Hose Moulding and Assembly Line: A Case Study by Pranish M. Naoghare, Atul R. More, Sandip S. Patil IRJET - March 2017.

$34^{\text {th }}$ Invest International Conference Magazine Mumbai 2019

https://diygearsupply.com/diy-guides/backpack/

https://lifehacker.com/how-to-design-and-sew-a-backpack-1598587633 